\title{
Superneutrality of Money under Open Market Operations
}

\author{
Stefan Homburg \\ Hannover Economic Papers (HEP) No. 541 \\ ISSN 0949-9962 \\ Published: Review of Economics 66 (3), pp. 289-302. \\ doi:10.1515/roe-2015-1003 \\ School of Economics and Management, Leibniz University \\ of Hannover, Germany. Phone: +49 511 762-5633. Email: \\ homburg@fiwi.uni-hannover.de.
}

Abstract: Monetary policy is superneutral in an overlapping generations model. Previous authors have argued that superneutrality does not hold in such a setting. However, the standard results rely on the counter-factual premise of helicopter money and are overturned if money creation through open market operations is taken into account. This result suggests that a more realistic representation of monetary policy may generally be helpful.

Keywords: Superneutrality, open market operations, seigniorage, monetary policy, overlapping generations.

JEL-Classification: E43, E52, H55 


\section{Introduction}

Do money balances crowd out real capital? Or, putting it in terms of monetary policy, would an easy-money policy boost capital formation and economic growth by making hoardings more expensive? In an early contribution to the literature, conducted mostly by means of graphs, Tobin (1965) answered these questions in the affirmative by arguing that inflation leads investors to substitute real capital holdings for money. The so-called Tobin effect was soon challenged by Sidrauski (1967) who used an optimizing model with an immortal agent to demonstrate that monetary policy leaves real variables unaffected.

Superneutrality of money means that money growth has no impact on real variables other than real money balances. This analysis disregards short-run frictions and is relevant to an economy that has become accustomed over a long period of time to a constant money growth rate, $m$. The question is whether a one-time shift in the money growth rate to $m^{\prime}>m$ would change consumption, output, or investment permanently. Whereas Sidrauski's superneutrality result indicates that accelerating money growth would not have such effects in steady states, Fischer (1979) and Asako (1983) considered non-neutralities arising during transitions.

Weiss (1980) and Drazen (1981) studied superneutrality in an overlapping generations model without operative bequests and showed that inflation indeed stimulates capital formation, thus reaffirming the Tobin effect. In perhaps the most advanced treatment of the issue, Abel (1987) and Gahvari (1988, 2007) noted a subtle issue with the preceding studies: Money creation redistributes income among generations; see also Crettez et al. (1999), Bhattacharya et al. (2005) and Ireland (2005). While policy changes are not superneutral per se, the government might make them effectively superneutral by using suitable lump-sum taxes and transfers. Taxes and transfers are not required in the Sidrauski model because the immortal agent hides all redistributive effects of monetary policy, as it does in any Ricardian model.

This paper introduces a deeper and stronger proposition regarding superneutrality. The proposition does not rely on steady state assumptions but holds for arbitrary equilibrium paths. Superneutrality is obtained not just in the long run but also during the transition. And, most importantly, lump-sum taxes and transfers, whose feasibility is arguable, become redundant.

The new proposition emerges from a single change in assumptions. Since Friedman (1969), monetary theory habitually employs the fiction of a helicopter that allots money to households (or to the government which, in turn, passes it on to households via transfers or tax rebates). This representation is not at all consistent with the actual process of money creation: With only certain exceptions such as Zimbabwe or war financing, central banks create money through open market operations, i.e., bond purchases. The law typically prohibits instantaneous distribution of fresh money and instead obliges the central bank to use revenue from money creation to acquire bonds (or to lend which, in a stylized model, amounts to the same thing). Seigniorage, i.e., the amount of money paid out, does not equal the increase in the money 
stock but is calculated from balance sheets and earnings statements that document central bank profits. Of course, this convention leaves the present value of seigniorage unaffected. Replacing helicopter money by open market operations, however, has an important impact on the timing of seigniorage, and on real variables and policy incentives. Until now, such effects have not been analyzed.

It should be emphasized at the outset that the present analysis differs crucially from the Wallace-Sargent irrelevance propositions, which state that open market operations have neither real nor nominal effects. Wallace (1981: 269) and Sargent (1987: 253) implicitly assume that bonds do not dominate money in return; both yield a nominal interest rate of zero. Under this unrealistic premise, which drives the result, money irrelevance is unsurprising: Wallace and Sargent essentially model "open market purchases" as an exchange of five dollar notes for ten dollar notes, an operation that no one would deem to be effectual. In contrast to this strand, the present approach represents money and bonds as two distinct assets with different yields. In this case, open market operations do affect nominal variables. The study focusses on policies of an independent central bank which are conducted without an expectation that law-makers will make accommodating tax or transfer adjustments.

The paper is organized as follows. Section 2 presents an otherwise standard model in which money is created through open market operations. Under this specification, monetary policy is superneutral even outside of steady states and with finitely lived agents. Section 3 compares the new proposition with the standard result in this field, arguing that helicopter money reduces the capital stock in much the same manner as an unfunded pension system: Both policies redistribute income among generations, and higher inflation reduces the extent of this redistribution. By contrast, open market operations inhibit intergenerational redistribution in the first place since the seigniorage resulting from money creation is not entirely transferred to to contemporary individuals but is distributed mainly to the future generations. Section 4 concludes the paper with the broader suggestion that using open market operations yields a sharper conceptual separation of monetary and fiscal issues. Open market money allows studying monetary effects in isolation while helicopter money intermingles monetary and fiscal redistributive impacts.

\section{Model and Main Result}

Consider a one-sector economy encompassing many identical households and firms in addition to a central bank. Time is divided into discrete periods, $t=1,2, \ldots$ Output can be used for consumption or investment. Moreover, there are two financial assets, money and bonds. Money bears no interest. Bonds issued in period $t$ are redeemable and pay interest in period $t+1$, at a nominal rate $i_{t}$ which is fixed in advance.

The central bank creates money by means of bond purchases in the amount of $B_{t}^{c b}>0$, during each period. The accrued interest income is distributed in the fol- 
lowing period as seigniorage, $\sigma_{t+1}$. The central bank's balance sheet and earnings statement take the form

$$
M_{t}=B_{t}^{c b} \quad \text { and } \quad \sigma_{t+1}=i_{t} B_{t}^{c b} .
$$

Abstracting from operating expenses, the two equations describe actual central bank operations quite realistically. The key point is that the central bank does not pay out the entire amount of newly created money via the proverbial helicopter, but disseminates only its interest income. In the previous literature, any increase in the money stock $\Delta M$ is paid out instantaneously as seigniorage $\sigma=\Delta M$. Under the present rule of the game, and assuming a constant interest rate for the moment, seigniorage will increase by $i \Delta M$ in the following period and up to infinity; this stream is distributed to the elderly and to all following generations. The present value of total seigniorage payments (which, using the formula for perpetuities, equals $i \Delta M / i$ in the latter case) is the same under both specifications, but the time profiles and the recipients differ.

Considering the enormous jumps in central bank balance sheets that occurred during the period of "quantitative easing", the difference between helicopter allotments and the present specification is notable. For instance, if the U.S. Federal Reserve System had operated in accordance with the standard macroeconomic model, it would have distributed $\$ 1,028 \mathrm{bn}$. in 2012 . However, the actual remittances to the treasury during that year amounted to $\$ 88 \mathrm{bn}$.

Firms accept nominal wage rates $W_{t}$, price levels $P_{t}$, and nominal interest rates $i_{t}$. They choose positive labor demands $N_{t}^{d}$ and real capital stocks $K_{t}^{d}$ to maximize profits $\Pi_{t}$. Investment is financed by issuing fixed interest bonds in an amount equal to $B_{t}^{s}$. Thus, firms solve the following program for all $t=1,2, \ldots$

(2) $\max _{N_{t+1}^{d}, K_{t}^{d}, B_{t}^{s}} \quad \Pi_{t+1}=P_{t+1} F\left(N_{t+1}^{d}, K_{t}^{d}\right)-W_{t+1} N_{t+1}^{d}-\left(1+i_{t}\right) B_{t}^{s} \quad$ s.t. $\quad B_{t}^{s}=P_{t} K_{t}^{d}$.

In the first period, firms optimize over $N_{1}^{d}$ only and take as given the historic values $K_{0}^{d}$ and $B_{0}^{s}$. The gross production function is smooth, strictly increasing and strictly quasi-concave. It displays constant returns to scale and satisfies the Inada properties. In equilibrium, profits vanish. Defining the rate of inflation and the real interest rate

$$
1+\hat{P}_{t+1}=\frac{P_{t+1}}{P_{t}} \quad, \quad 1+r_{t+1}=\frac{1+i_{t}}{1+\hat{P}_{t+1}},
$$

the marginal productivity of labor equals the real wage rate at the individual optimum, whereas the marginal productivity of capital equals the real interest factor:

$$
\frac{\partial F\left(N_{t}^{d}, K_{t-1}^{d}\right)}{\partial N_{t}^{d}}=\frac{W_{t}}{P_{t}} \text { and } \frac{\partial F\left(N_{t+1}^{d}, K_{t}^{d}\right)}{\partial K_{t}^{d}}=1+r_{t+1} .
$$

Households live for two periods and take prices as given. In the first period, they supply an exogenous amount of labor $N_{t}$ which is measured in efficiency units, such that changes in labor supply reflect population growth, human capital formation, and labor-augmenting technical progress. Nominal wage income $W_{t} N_{t}$ is used to fi- 
nance positive first-period consumption expenditure $P_{t} C_{t}^{1}$ and the acquisition of bonds $B_{t}^{d}$ and money balances $M_{t}^{d}$. In the second period, households use these bonds, accrued interest, and money balances to finance positive retirement consumption expenditure $P_{t+1} C_{t+1}^{2}$. In accordance with the previous literature, firm profits and seigniorage are distributed equally among the elderly. Generation zero makes no choices and only consumes in accordance with its second-period budget constraint. Every subsequent generation selects consumption, bond holdings and money balances to maximize a smooth utility function that is strictly increasing and strictly quasi-concave, with indifference surfaces that do not touch the axes. As discussed below, utility is also separable in real money balances, which means that marginal rates of substitution between present and future consumption are independent of real money balances.

$$
\begin{aligned}
& \max _{C_{t}^{1}, C_{t+1}^{2}, B_{t}^{d}, M_{t}^{d}} U\left(C_{t}^{1}, C_{t+1}^{2}, M_{t}^{d} / P_{t}\right) \\
& \text { s.t. i) } P_{t} C_{t}^{1}=W_{t} N_{t}-B_{t}^{d}-M_{t}^{d}, \\
& \text { ii) } P_{t+1} C_{t+1}^{2}=\left(1+i_{t}\right) B_{t}^{d}+M_{t}^{d}+\Pi_{t+1}+\sigma_{t+1} .
\end{aligned}
$$

From the first-order conditions, it follows that the saving decision is governed by the real interest rate, whereas the opportunity costs of money balances depend on the nominal interest rate:

$$
\frac{\partial U / \partial C_{t+1}^{2}}{\partial U / \partial C_{t}^{1}}=\frac{1}{1+r_{t}} \quad \text { and } \quad \frac{\partial U / \partial\left(M_{t}^{d} / P_{t}\right)}{\partial U / \partial C_{t}^{1}}=\frac{i_{t}}{1+i_{t}} .
$$

A perfect foresight equilibrium is a sequence of strictly positive prices $\left(P_{t}, i_{t}, W_{t}\right)$ such that in all periods $t=1,2 \ldots$, markets clear

$$
\begin{gathered}
C_{t}^{1}+C_{t}^{2}+K_{t}^{d}=F\left(N_{t}^{d}, K_{t-1}^{d}\right), \\
B_{t}^{d}+B_{t}^{c b}=B_{t}^{s}, \\
N_{t}^{d}=N_{t},
\end{gathered}
$$

where private demands and supplies are chosen optimally in the manner outlined above. The equilibrium is subject to initial stocks $K_{0}^{d}>0$ and $B_{0}^{d}+B_{0}^{c b}=B_{0}^{s}$, exogenous labor supplies $N_{t}>0$, and policy decisions $M_{t}>0$. By Walras' Law, the three market clearing conditions above imply that $M_{t}^{d}=M_{t}$, for all $t$.

The model could be augmented with government bonds which are issued in a constant amount $B_{t}^{g}$ in each period. Under such a generalization, the second equilibrium condition would read $B_{t}^{d}+B_{t}^{c b}=B_{t}^{s}+B_{t}^{g}$, and the central bank could buy government bonds, as most central banks did before they turned to quantitative easing. Adding government bonds, however, would not change the following results because private bonds and government bonds would be perfect substitutes. Therefore, in order to simplify notation and to focus on the essential points, government bonds are neglected without loss of generality. 
Before moving to the main result, it is notable that consumption by the elderly equals output minus real wages. Substituting seigniorage (1) into the second constraint in (5) yields:

$$
C_{t}^{2}=\frac{\left(1+i_{t-1}\right) B_{t-1}^{d}+M_{t-1}^{d}+\Pi_{t}+i_{t-1} B_{t-1}^{c b}}{P_{t}}=F\left(N_{t}^{d}, K_{t-1}^{d}\right)-\frac{W_{t} N_{t}^{d}}{P_{t}} .
$$

The right-hand equality follows using profit definition (2) and the accounting identity $B_{t-1}^{d}+B_{t-1}^{c b}=B_{t-1}^{s}$. Hence, the elderly obtain the entire capital income. This feature is in line with the studies discussed in the introduction, in which the older generation holds the real capital stock directly. Unexpected increases in the price level diminish the real values of bond and money holdings but also entail positive profits. This windfall gain offsets the windfall loss.

The following proposition envisions a one-time shift in monetary policy. Until some period $t^{*}$, the money stock grows at the constant rate $m$. Thereafter, growth accelerates, and the money stock in period $t^{*}+1$ is the first which results from the higher growth rate $m^{\prime}$. It will be shown that the acceleration is superneutral.

Proposition: Assume an equilibrium with a constant money growth rate $m$. Then, the announcement in $t^{*}$ of a money growth rate $m^{\prime}>m$, effective from period $t^{*}+1$, raises $1+\hat{P}_{t+1}$ and $1+i_{t}$ by the common factor $\left(1+m^{\prime}\right) /(1+m)$, for all $t \geq t^{*}$, diminishes real money balances from period $t^{*}$ on, and leaves all other real variables unaffected.

Proof: The proof does not use calculus but is conducted in a more elementary way. It proceeds from the equilibrium assumption and shows that the asserted changes leave individual incentives and constraints unaffected. As a consequence, individuals stick to their original decisions, except for real money balances, so that the original equilibrium allocation is still supported.

i) By hypothesis and definition (3), the policy change has no impact on real interest rates $r_{t+1}$, for all $t \geq t^{*}$. Hence, by (4), real capital stocks remain unaffected. Labor market clearing entails that the same is true for real wage rates $W_{t} / P_{t}$. Nominal wages adjust in accordance with prevailing price levels.

ii) As output and real wages in period $t^{*}$ depend only on exogenous variables, equation (8) implies that second-period consumption of generation $t^{*}-1$ remains the same.

iii) For all generations $t \geq t^{*}$, combining the budget constraints (5) and inserting seigniorage and zero profits yields

$$
C_{t}^{1}+\frac{C_{t+1}^{2}}{1+r_{t+1}}+\frac{M_{t}^{d}}{P_{t}} \frac{i_{t}}{1+i_{t}}=\frac{W_{t} N_{t}}{P_{t}}+\frac{B_{t}^{c b}}{P_{t}} \frac{i_{t}}{1+i_{t}} .
$$

Because $i_{t}$ rises in all periods $t \geq t^{*}$, the opportunity costs of holding money (the third summand on the left) also increase. Due to the equilibrium condition $M_{t}^{d}=M_{t}$ and the identity $M_{t}=B_{t}^{c b}$, this increase is exactly matched by an equivalent increase in seigniorage (the second summand on the right). Hence, the original choice 
$\left(C_{t}^{1}, C_{t+1}^{2}\right)$ of present and future consumption can be maintained. With utility separable in real money balances, it is also optimal to maintain that choice.

iv) However, owing to the higher opportunity costs, all generations $t \geq t^{*}$ diminish their real money balances, which are a normal good under separable utility. This completes the proof.

To grasp the intuition behind this result, it is convenient to imagine a stationary economy with a constant money stock and a constant price level. In period $t^{*}$, the central bank announces that it will begin increasing the money stock from the next period onward. This announcement induces investors to expect $P_{t^{*}+1}>P_{t^{*}}$, an impact that would boost investment demand but is offset by a corresponding increase in the nominal interest rate $i_{t}$. Because this rise occurs in period $t^{*}$, real money balances diminish as the nominal money stock remains constant, which entails a prompt jump in the price level. According to (8), the policy change does not affect the elderly in period $t^{*}$. The young - and all subsequent generations-face higher nominal interest rates and hold lower real cash balances. As is usual in frictionless models, a more expansionary policy increases the nominal interest rate through the Fisher effect (or expected inflation effect).

It should be emphasized that prices and interest rates increase in period $t^{*}$, although the money stock does not move before period $t^{*}+1$. This feature is consistent with the "endogenous money" view: Empirical research would find inflation to Granger cause money, although the money stocks are in fact exogenous. The early price movement results from the policy announcement, which ostensibly presents a shining example of an anticipated policy. However, there is a semantic issue here: Although the agents anticipate (in period $t^{*}$ ) the announced policy change that becomes effective in $t^{*}+1$, these agents did not anticipate in the periods before $t^{*}$ that the central bank would make such an announcement. The preceding literature on the superneutrality of money, with its focus on steady states, has not differentiated between announced and unannounced policy changes. This distinction becomes relevant in a fully specified general equilibrium model and triggers questions regarding the impact of unannounced policy changes.

Corollary: If, under the assumptions of the proposition, the policy change is not announced in period $t^{*}$, superneutrality of money still obtains. Interest and prices in period $t^{*}$ are unaffected, and inflation will overshoot in the following period.

Unaware of the policy change effective from period $t^{*}+1$ onward, private agents do not change their behavior in period $t^{*}$. In the following period, when the monetary expansion at a rate $m^{\prime}>m$ sets in (and is believed to be continued forever), inflation expectations and nominal interest are adjusted in proportion. Real money balances are also diminished, which induces an additional, one-time surge in the price level. As the combined effect of these two outcomes, inflation in period $t^{*}+1$ overshoots its new long-run level. Figure 1 depicts the behavior of the logarithm of the price level under announced and unannounced monetary policy changes, respectively, which have identical impacts before period $t^{*}$ and after period $t^{*}+1$. The blue solid line il- 
lustrates an announced policy change in which prices begin rising in period $t^{*}$ because expectations are revised and cash balances diminished. The red dotted line corresponds to an unannounced policy change that leaves all variables unaffected in period $t^{*}$ but induces a correspondingly stronger subsequent jump in the price level.

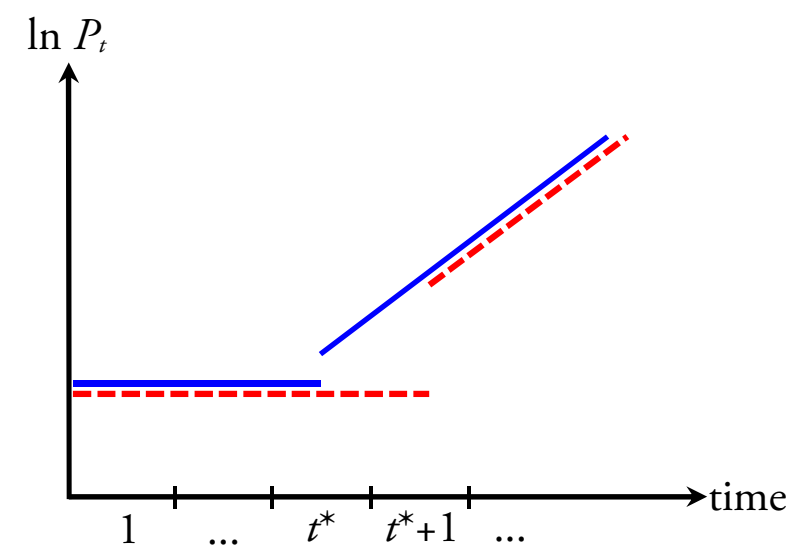

Figure 1: The blue solid line represents a policy change announced in period $t^{*}$; the price level rises immediately. The red broken line is an unannounced policy change.

Summing up, money is superneutral under open market operations. This assertion holds irrespective of whether or not the central bank announces its course. Policy changes have an impact on expost real interest rates which is immaterial because investment decisions depend only on the ex ante rates.

\section{Open Market Operations versus Helicopter Money}

To compare the above approach with the previous literature, it is useful to begin with a generalized description of monetary policy. The following equation represents the central bank's cash-flow statement, an accounting identity that holds in every period, regardless of other institutional constraints:

$$
\sigma_{t+1}+B_{t+1}^{c b}=M_{t+1}-M_{t}+\left(1+i_{t}\right) B_{t}^{c b} .
$$

The left-hand side shows central bank expenses on seigniorage and bond purchases, whereas the right-hand side displays central bank revenue from money creation, interest and bond redemptions. Inserting $B_{t}^{c b} \equiv M_{t}$ implies $\sigma_{t+1} \equiv i_{t} B_{t}^{c b}$ and yields equation (1) above, the open market model, in which the central bank distributes only its interest revenue as seigniorage. By contrast, inserting $B_{t}^{c b} \equiv 0$ yields the helicopter model, in which the full increase in the money stock is distributed as seigniorage:

$$
B_{t}^{c b}=0 \quad \text { and } \quad \sigma_{t+1}=M_{t+1}-M_{t} .
$$

Replacing (1) by (1') in the above model confirms the traditional findings of Weiss (1980), Drazen (1981), Abel (1987), and Gahvari (1988) that money will not be superneutral in a model with finitely lived agents. Before examining the impact of the change in assumptions more closely, it should be noted that the open market model and the helicopter model are identical in two important respects. 
First, both approaches consider a regime of monetary dominance with a central bank that is in a position to set money stocks autonomously, while the government accepts the implied seigniorage. Authors such as Sargent and Wallace (1981) and Waldo (1985) have studied open market operations in the context of fiscal dominance, in which equation (10) represents a consolidated central bank-government budget constraint and $\sigma_{t+1}$ represents the government's primary deficit, which is exogenous for the central bank. Under fiscal dominance, the central bank loses its ability to conduct independent monetary policy, which gives rise to the various paradoxes of monetarist arithmetic. Open market operations as analyzed here are not enforced by a government that wishes to finance a larger primary deficit but are undertaken by an independent central bank. This assumption resembles the institutional setup in most industrialized countries and yields a clear conceptual separation of monetary and fiscal policy.

Second, the open market model and the helicopter model share the assumption of preferences that are separable in real money balances. Without this premise, changes in real balances will either increase or diminish the real capital stock, depending on the reaction of households' intertemporal preferences. Because there is no systematic reaction, the literature has not studied this possible effect further. As the proof above suggests, an alternative sufficient condition for superneutrality would be that the compensated interest elasticity of real money demand vanishes.

Returning to the main argument, it will now be shown that the specification of the process of money creation has bold consequences for the real economy. The easiest way to see this begins with the equilibrium condition for the capital market in (7), which reads $B_{t}^{d}+B_{t}^{c b}=B_{t}^{s}$. Keeping in mind that investment is financed by bond issues, the capital stock assumes different equilibrium levels in the helicopter model and in the open market model:

$$
K_{t}=\frac{B_{t}^{d}}{P_{t}} \quad \text { versus } \quad K_{t}=\frac{B_{t}^{d}+M_{t}^{d}}{P_{t}} .
$$

With helicopter money, the capital stock equals households' real bond holdings, as shown in the left-hand equation. Under open market operations, the capital stock equals the sum total of households' bond and money holdings, as shown in the righthand equation, because equilibrium money demand equals the money stock and the latter, in turn, equals the central bank's bond holdings. Money does not crowd out real capital in the open market model but constitutes a transitory item: Investment is not solely financed by households' bond holdings but also by their money holdings, which are channeled to the firms through the central bank.

Figure 2 illustrates the consequences of this key finding for an assumed stationary economy. The blue solid line shows households' real money and bond holdings in the open market model. The red broken line represents households' real bond holdings only, which corresponds to the helicopter case. In the latter model, the capital stock is lowered by the amount of real money balances, as can be directly inferred 
from (11). The shortfall, which can be considered as public debt, has been paid out as seigniorage before the stationary state has been reached

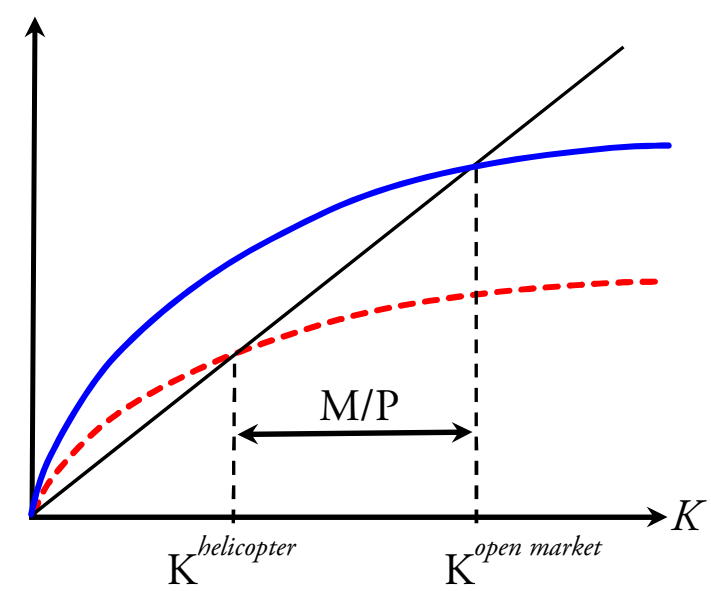

Figure 2: The blue solid line represents households' money plus bond holdings under open market operations. The red broken line represents households' bond holdings only, as in the helicopter model.

The upshot is that helicopter money resembles a pay-as-you-go pension scheme (PAYG) that taxes the young and distributes the revenue to the elderly. By contrast, money created through open market operations resembles a capital reserve (CR) system that invests all the contributions of the young in the bond market. Helicopter money entails a lower long-run capital stock than open market money in exactly the same way as a PAYG scheme entails a lower long-run capital stock as compared with a CR system. Helicopter money and PAYG are associated with (implicit) public debt that equals the reduction in the capital stock.

Considering helicopter money as a scheme of intergenerational redistribution, one might think that increasing inflation operates in the same manner as extending PAYG. However, quite the opposite is true: Higher inflation diminishes real money balances. As the latter represent public debt, accelerating money growth is equivalent to reducing that debt, i.e., is equivalent to phasing-out PAYG. The double arrow in figure 2 indicates that the steady state capital stock associated with the helicopter model changes with inflation and is bounded above by the capital stock of the open market model.

Tobin motivated monetary expansions with the argument that higher inflation would stimulate capital formation and growth. The open market model rejects this view because of superneutrality. Under helicopter money, Tobin is correct, but it must be borne in mind that the increase in the capital stock that follows the adoption of a more inflationary policy does not result from an efficiency gain but from redistribution at the expense of the elderly. Tobin's contention is analogous to Feldstein's (1976: 85) critique that PAYG pension systems produce a "distortion in saving" and diminish the national capital stock. As Breyer (1989) showed in a seminal paper, steady states with and without PAYG are not Pareto ordered, and phasing out PAYG only redistributes income from the old to the young. In the context of pen- 
sion reform, efficiency issues arise if PAYG taxes distort the labor market; see Homburg (1990) or Breyer and Straub (1993). Regarding monetary policy, higher inflation produces an excess burden because individuals economize on their real money holdings although the latter are a free lunch socially.

\section{Conclusion}

This paper tried to represent the process of money creation in a more realistic fashion. In this respect, it is surely only a small step, because the model neglects commercial banks in the same way as the preceding literature. Nevertheless, two conclusions emerge that seem notable.

First, monetary policy is superneutral in a model with finite lives if the common fiction of helicopter money is replaced by money that is created through open market operations. This single change in assumptions eliminates the Tobin effect and alters the role of real balances fundamentally; money no longer crowds out real capital. The economic intuition behind this result is startlingly simple: Money balances crowd out households' bond holdings, but this impact is exactly matched by an increase in central bank bond holdings. Therefore, total bond holdings, which are used for financing the real capital stock, remain unaffected.

From an applied point of view, the message of the superneutrality proposition is not that monetary policy will be neutral in the real world, where frictions abound. Instead, it indicates that policy makers do not face a trade-off between price stability and the desire to stimulate investment. The Tobin effect simply rests on partial economic thinking. The same is true for the diametrically opposed conviction of monetary practitioners that central banks are able to enhance credit. In general equilibrium, central bank credit creation, or bond demand, is counterbalanced by private credit reduction, which results in essentially no effect on total credit supply.

Second, the analysis above suggests that substituting open market operations for helicopter money may be helpful not only with respect to superneutrality but also in general, because it allows a sharper separation of monetary and fiscal policies. Theorists often face an uneasy choice. They wish to make their models realistic, but more realism entails intractability, and suspicious assumptions have to be made. Representing the process of money creation more realistically is an exception to this rule, as the improvement comes with no price. Compared with the standard approach, the open market model is simpler rather than more intricate, because it removes the redistributive effects of monetary policy in the first place and yields a sharp separation of monetary and fiscal measures. Friedman's helicopter may be an appropriate pedagogical device - a modern version of the sudden gold discoveries to which the classical writers referred. However, with respect to a full-fledged contemporary macro model, there is no excuse for a counterfactual representation of money creation that intermingles monetary and fiscal measures.

As a caveat, the above results pertain to non-Ricardian economies with finitely lived agents, where government debt, pension policies, and monetary operations matter. 
In a Ricardian framework, by contrast, temporal effects of fiscal or monetary measures are absorbed by the assumed immortal agent. Such an analysis renders budget deficits and pension plans irrelevant and also ensures superneutrality of money. Its relevance, however, can be seriously questioned. The non-Ricardian approach is adequate if one believes that the timing of public policies is important in reality.

The paper can be extended in various directions. A particularly promising course for future research would be to consider open market operations under less stringent assumptions from a public choice perspective. In a recent speech, Adair Turner (2013: 3) emphasized that the prohibition of helicopter money "has gained within our political economy the status of a taboo, as a policy characterized not merely as in many circumstances and on balance undesirable, but as something we should not even think about let alone propose." Whereas theorists prefer helicopter money, most policy makers flatly reject the very idea. But why? Keeping in mind that money creation through open market operations spreads seigniorage over an infinite horizonwhereas helicopter seigniorage is allotted in a one-shot fashion to the presently living - the modern institutional setup may have a profoundly distributive rationale. Following this view, open market operations serve as an insurance device that protects specific cohorts or groups of people from exploitation. Moreover, the design of money creation may alter incentives to support inflationary policies or may affect the inconsistency problems studied by Kydland and Prescott (1977). 


\section{References}

Abel, A. B. (1987) Optimal Monetary Growth. Journal of Monetary Economics 19: 437-450.

Asako, K. (1983) The Utility Function and the Superneutrality of Money on the Transition Path. Econometrica 51: 1593-1596.

Bhattacharya, J., J. Haslag and S. Russell (2005) The Role of Money in Two Alternative Models: When is the Friedman Rule Optimal, and Why? Journal of Monetary Economics 52: 1401-1433.

Breyer, F. (1989) On the Intergenerational Pareto Efficiency of Pay-as-you-go Financed Pension Systems. Journal of Institutional and Theoretical Economics 145: 643658.

Breyer, F. and M. Straub (1993) Welfare Effects of Unfunded Pension Systems When Labor Supply is Endogenous. Journal of Public Economics 50: 77-91.

Crettez, B., P. Michel and B. Wigniolle (1999) Cash-in-advance Constraints in the Diamond Overlapping Generations Model: Neutrality and Optimality of Monetary Policies. Oxford Economic Papers 51: 431-452.

Drazen, A. (1981) Inflation and Capital Accumulation under a Finite Horizon. Journal of Monetary Economics 8: 247-260.

Feldstein, M. (1976) Social Security and Saving: The Extended Life Cycle Theory. American Economic Review (PP) 66: 77-86.

Fischer, S. (1979) Capital Accumulation on the Transition Path in a Monetary Optimizing Model. Econometrica 47: 1433-1439.

Friedman, M. (1969) The Optimum Quantity of Money and Other Essays. London: Macmillan.

Gahvari, F. (1988) Lump-sum Taxation and the Superneutrality and Optimum Quantity of Money in Life Cycle Growth Models. Journal of Public Economics 36: 339-367.

Gahvari, F. (2007) The Friedman Rule: Old and New. Journal of Monetary Economics 54: 581-589.

Homburg, S. (1990) The Efficiency of Public Pension Schemes. Journal of Institutional and Theoretical Economics 146: 640-647.

Ireland, P. N. (2005) The Liquidity Trap, the Real Balance Effect, and the Friedman Rule. International Economic Review 46: 1271-1301.

Kydland, F. E. and E. C. Prescott (1977) Rules Rather than Discretion: The Inconsistency of Optimal Plans. Journal of Political Economy 85: 473-492.

Sargent, T. J. (1987) Dynamic Macroeconomic Theory. Cambridge: Harvard University Press.

Sargent, T. J. and N. Wallace (1981) Some Unpleasant Monetarist Arithmetic. Federal Reserve Bank of Minneapolis Quarterly Review 5: 1-17. 
Sidrauski, M. (1967) Rational Choice and Patterns of Growth in an Monetary Economy. American Economic Review 57: 534-544.

Tobin, J. (1965) Money and Economic Growth. Econometrica 33: 671-684.

Turner, A. (2013) Debt, Money, and Mephistopheles: How Do We Get Out of This Mess? Group of Thirty Occasional Paper 87, Washington, D.C.

Waldo, D. G. (1985) Open Market Operations in an Overlapping Generations Model. Journal of Political Economy 93: 1242-1257.

Wallace, N. (1981) A Modigliani-Miller Theorem for Open-Market Operations. American Economic Review 71: 267-274.

Weiss, L. (1980) The Effects of Money Supply on Economic Welfare in the Steady State. Econometrica 48: 565-576. 